\title{
Profitability and Resource Utilization in Groundnut Production under Solar Irrigation System
}

\author{
Yash Gautam $^{1^{*}}$ and O.P. Singh ${ }^{2}$ \\ Department of Agricultural Economics, Institute of Agricultural Sciences, BHU, \\ Varanasi, India \\ *Corresponding author
}

\begin{tabular}{l} 
Ke y w o r d s \\
$\begin{array}{l}\text { Groundnut } \\
\text { production, Solar } \\
\text { Irrigation System }\end{array}$ \\
Article Info \\
$\begin{array}{l}\text { Accepted: } \\
\text { 04 October } 2020 \\
\text { Available Online: } \\
10 \text { November } 2020\end{array}$ \\
\hline
\end{tabular}

\section{A B S T R A C T}

Groundnut is commonly called the poor man's nut. It is an important oilseed and food crop because of high protein content. Groundnut is a major oil seed crop of India and plays a major role in minimising the vegetable oil deficit in the country. In India, groundnut has been a significant dietary component, consumed directly as well as used in processed food. Although, major portion of groundnut kernels are used for oil extraction, but still it has significant use in cottage industry. After oil extraction process, groundnut cake is obtained as a by-product or residue. The roots of the plant help to enrich the soil and the vines and serve as excellent fodder for cattle. When the cake is powdered and extracted in solvent, it yields defatted groundnut meal. Groundnuts in India are available throughout the year due to a two crop cycle which are harvested in March and October. Rajasthan is the second highest groundnut producing state in India. In 2018-19, groundnut was cultivated on 0.67 million hectares area in the state, producing to a level of 1.38 million tonnes. Rajasthan contributed up to 20.65 per cent of the total groundnut production of the country. Cost analysis suggested that the total cost of groundnut cultivation in Rajasthan was Rs. $74,415.29$. Highest contribution in the cost of cultivation was of human labour followed by seed cost. Net return including irrigation charges was Rs.30,350.31 per hectare. Input productivity was analysed using cobb Douglas production function and it was found that inputs like human labour, machine labour and seed were underutilised. Although, groundnut cultivation gave profit but it can be made more profitable by efficient utilisation of underutilised and overused inputs.

\section{Introduction}

Groundnut (Arachis hypogaea) also known as peanut is commonly called the poor man's nut. It is a species in the legume or "bean" family. Peanuts are known other local names such as earthnuts, ground nuts, goober peas, monkey nuts, pygmy nuts and pig nuts. Despite its name and appearance, it is not a nut rather a legume. Like sorghum is an important source of feed, fodder and bio-fuel apart from food, ground nut also has diverse uses (Gautam and Singh, 2018). It is an important oilseed and food crop because of high protein content. Groundnut is a major oil seed crop of India and plays a major role in minimising the vegetable oil deficit in the country. In India, groundnut has been a significant dietary component, consumed directly as well as used in processed food. 
Although, major portion of groundnut kernels are used for oil extraction, but still it has significant use in cottage industry. After oil extraction process, groundnut cake is obtained as a by-product or residue. Groundnut cake contains about 43 to 65 percent protein and 6 to 20 percent fat plus some B-group vitamins depending upon the method of extraction. Incidentally, NASA of the United States of America has selected groundnut as a possible food for the Advanced Life Support system for extended space missions (Nautiyal et al., 2002). The roots of the plant help to enrich the soil and the vines serve as excellent fodder for cattle. The nuts, in addition to being the most consequential source of edible oil, are useful in numerous other ways. When the cake is powdered and extracted in solvent, it yields defatted groundnut meal. Thus the crop has gained great popularity, based on its diverse use and the significant financial returns it brings to the grower.

Groundnuts in India are available throughout the year due to a two crop cycle which are harvested in March and October. India is the second largest producer of groundnuts in the world. Indian groundnuts are available in different varieties: Bold or Runner, Java or Spanish and Red Natal. The main Groundnut varieties produced in India are Kadiri-2, Kadiri-3, BG-1, BG-2, Kuber, GAUG-1, GAUG-10, PG-1, T-28, T-64, Chandra, Chitra, Kaushal, Parkash, Amber etc. The country has exported 6,64,442.93 MT of groundnuts to the world for the worth of ₹ 5,096.34 crores/ 711.38 USD Millions during the year 2019-20 (APEDA).Indian groundnut is highly preferred in the international market for the table purpose. It is because of its characteristic flavour, nutty taste and crunchy texture. Indian groundnut also has relatively longer shelf life making it a product with better export opportunity.

China and India together are the world's leading groundnut producers accounting for approximately 60 percent of the production and 52 percent of the crop area (Nautiyal et al., 2002). India cultivated about 4.81 million hectares and produced6.69 million tonnes of groundnut with the productivity level of 1393 $\mathrm{kg} / \mathrm{ha}$ in 2018-19 (GoI, 2019). In recent times, production level has been unstable because a number of constraints such as the cultivation of the crop on marginal lands under rainfed conditions, frequent drought stress due to vagaries of monsoon, incidence of pest and diseases, low and inefficient input use, etc. One major factor that contributes in the fluctuation of production level is the availability of good quality seeds to the farmers. Groundnut seeds are big in size and have low multiplication ratio compared to cereals. This makes it difficult to produce good quality seeds and their timely supply to the farmers.

Protein calorie malnutrition (PCM) is one of the serious issues regarding food security which has not been addressed seriously in India. The reason for low groundnut protein consumption in India is that out of 6 million Mt of groundnuts produced every year, 80 percent are utilized for oil extraction, 12 percent for seed purpose, 2 percent for export and the remaining for edible purposes. The protein rich cake resulting from oil extraction is fed to the animals as protein supplement (Nautiyal et al., 2002). Therefore, significant amount of groundnut protein never reaches the plates of the consumer.

Rajasthan is the second highest groundnut producing state in India. In 2018-19, groundnut was cultivated on 0.67 million hectares area in the state, producing to a level of 1.38 million tonnes. Rajasthan contributed up to 20.65 per cent of the total groundnut production of the country. Groundnut is cultivated mostly under irrigated condition in the state because of its high water demand. In 2015-16, 87.6 per cent of the area of the groundnut crop was cultivated under irrigated 
condition (GoI, 2019). With the increasing fluctuation in monsoon rainfall over the years, farmers are forced to set up irrigation pumps to meet their irrigation requirements. Since, the initial cost of diesel pumps is very low and they are easily available in the market, so, farmers set them up at their farms. But with increasing diesel prices and high water requirement of the crop it will be very difficult for the farmers to keep groundnut production profitable because of high diesel cost. This will also put a burden on the government treasury in the form of subsidy on diesel.

Use of diesel pump is also harmful environmentally. Burning one litre of diesel produces $2.6 \mathrm{Kg}$ of carbon dioxide. Therefore, it can be easily deduced that the amount of carbon dioxide that would be released in the atmosphere only by irrigating groundnut crop for one season. According to Klynveld Peat Marwick Goerdeler, India uses more than 4 billion litres of diesel and around 85 million tons of coal per annum to support water pumping for irrigation. If 1 million diesel pumps were replaced with equal number of solar pumps then it would result in reduction of diesel use by 9.4 billion litres over the life cycle of solar pumps which translates into diesel subsidy saving of Rs 8,400 Crore and $\mathrm{CO}_{2}$ emission abatement of $25.3 \mathrm{Mn}$ Tonnes (KPMG, 2014). Hence, government has launched several schemes to promote the installation and use of solar irrigation pumps. KisanUrja Suraksha Utthaan Mahabhiyaan (KUSUM) scheme is the most recent initiative taken by the government in the direction of promotion of solar energy. Under the scheme, individual farmers will be supported to install solar agriculture irrigation pumps of capacity up to $7.5 \mathrm{HP}$. Central finance assistance of 30 per cent of the benchmark cost of the solar irrigation pump will be provided. The State Government will give a subsidy of 30 per cent and the remaining 40 per cent will be provided by the farmer. Bank finance may be made available for farmer contribution. Individual farmers having grid connected irrigation pump will be supported to solarise their pumps. Also, farmers will be allowed to sell the excess solar power to DISCOM's. Considering the importance of the crop and the environmental effects of diesel used for irrigation, an economic analysis of groundnut production under solar irrigation system was conducted.

\section{Materials and Methods}

The study was based on primary data collected with the help of survey schedule. Cost of cultivation and return over different costs were calculated using cost concept suggested by CACP (Gautam, 2018). Cobb Douglas production function was used to analyse the resource use efficiency of the inputs.

Cost $\mathrm{A}_{1}=$ All actual expenses in cash and kind incurred in production by the owner. It includes :

Cost $A_{2}=$ Cost $A_{1}+$ rent paid for leased in land

Cost $\mathrm{B}_{1}=$ Cost $\mathrm{A}_{1}+$ interest on value of owned capital asset (excluding land)

Cost $\mathrm{B}_{2}=$ Cost $\mathrm{B}_{1}+$ rental value of owned land

Cost $\mathrm{C}_{1}=$ Cost $\mathrm{B}_{1}+$ imputed value of family labour.

Cost $\mathrm{C}_{2}=$ Cost $\mathrm{B}_{2}+$ imputed value of family labour

Cost $C_{3}=\operatorname{Cost} C_{2}+10 \%$ of $C_{2}$

\section{Results and Discussion}

\section{Cost concept analysis}

Per hectare operational cost and fixed cost incurred in the cultivation of groundnut under solar irrigation system is presented in the Table 1. It was found that the average total 
cost of cultivation was $₹ 74,415.29$, out of which operational cost was ₹ 48,237.28 and fixed cost amounted to ₹ 19,412.98. The percentage contribution of operational cost in the total cost was $64.82 \%$ and that a fixed cost was $26.09 \%$. Managerial cost was estimated to be ₹ 6765.03 .

Figure 1 shows the share of major inputs in the cost of cultivation of groundnut under solar irrigation system. It was observed that highest contribution in the total cost was of human labour ( 25 per cent), seed (18 per cent) and machine labour ( 7 per cent), fertiliser and manual ( 6 per cent) irrigation ( 6 per cent). The fixed cost contributed to the extent of 26 per cent in the total cost.

Cost of cultivation as suggested by cost concept Commission on Agricultural Cost and Prices (CACP) is shown in table 2. It can be observed it was observed that Cost A1 and A2 were ₹ 34,820.05 because farming was not done on leased-in-land by any farmer in the study area. Cost B1, B2, C1, C2, C3 were estimated to be ₹ 35,446.28, ₹ 52,190.53, ₹ $50,906.02$, ₹ $67,650.27$, and ₹ 74,415.29 respectively.

Table 3 shows the returns of groundnut under solar irrigation system. It was estimated that the return from main product and by product was equal to ₹ 90,693.74 and ₹ 9751.67 respectively. The net return was ₹ 26,030.12. Under solar irrigation system, farmer didn't have to pay any irrigation charge because farmer had installed solar pump on their farm and operation of solar pump doesn't require any additional input or charges. Therefore the irrigation charges that farmer had to pay before the installation of solar pump was saved. Hence, that irrigation charge which was saved was considered to be the part of the income of the farmer. So, the net income of the farmer after including irrigation charges was estimated to be ₹ 30,350.31.

\section{Resource use efficiency}

The value of coefficient of multiple determination capital $\mathrm{R}$ square was 0.8059 . It indicates that 80.59 per cent variation in logarithmic value of gross returns was explained by the independent variables (human labour, machine labour, seed, fertiliser, irrigation and manure) included in the regression model.

The coefficient of elasticity of production of human labour turned out to be positive and significant. It means that for every 1 per cent increase in human labour there be an increase in the gross return by 0.4047 per cent keeping the other variable resources considered in the equation constant at their geometric mean level. Similarly, coefficient of elasticity of production of machine labour, seed and irrigation were positive and significant. However the coefficient of elasticity of production of fertiliser was negative and insignificant whereas the coefficient of elasticity of production of manure was positive and insignificant.

The sum of the regression coefficients of variables was more than one i.e. $\sum b_{i}=1.2083$ which meant that there was increasing returns to scale. Also, the inputs were not used optimally. If the inputs which were positive and significant like human labour, machine labour and seed were used increasingly and optimally, production will also increase (Table 4).

In conclusion, cost concept analysis showed that the groundnut production was profitable even in solar irrigated condition. Net return of the farmer was ₹ 30,350.31 per ha. Regression analyses shows that there is a scope of increase in the groundnut production by the optimal utilisation of several underutilised inputs like human labour, machine labour, seed and irrigation. 
Table.1 Item wise breakup of cost of production (₹ per Ha.)

\begin{tabular}{|c|c|c|c|}
\hline & \multicolumn{2}{|l|}{ Costs } & Amount \\
\hline $\mathbf{A}$ & \multicolumn{2}{|l|}{ Operational Cost } & $48,237.28$ \\
\hline \multirow[t]{4}{*}{1} & \multirow[t]{4}{*}{ Human Labour } & Family & $15,459.74$ \\
\hline & & Attached & 0.00 \\
\hline & & Casual & $3,207.81$ \\
\hline & & Total & $18,667.55$ \\
\hline \multirow[t]{3}{*}{2} & \multirow[t]{3}{*}{ Animal Labour } & Hired & 4.82 \\
\hline & & Owned & 42.84 \\
\hline & & Total & 47.66 \\
\hline \multirow[t]{3}{*}{3} & \multirow[t]{3}{*}{ Machine Labour } & Hired & $3,763.95$ \\
\hline & & Owned & $1,682.90$ \\
\hline & & Total & $5,446.85$ \\
\hline 4 & \multicolumn{2}{|l|}{ Seed } & $13,159.97$ \\
\hline \multirow[t]{3}{*}{5} & \multirow[t]{3}{*}{ Fertilizer \& Manure } & Fertilizer & $1,938.35$ \\
\hline & & Manure & $2,849.32$ \\
\hline & & Total & $4,787.67$ \\
\hline 6 & \multicolumn{2}{|l|}{ Insecticides } & $1,251.11$ \\
\hline 7 & \multicolumn{2}{|l|}{ Irrigation Charges } & $4,320.19$ \\
\hline 8 & \multicolumn{2}{|l|}{ Miscellaneous } & 0.00 \\
\hline 9 & \multicolumn{2}{|c|}{ Interest on Working Capital } & 556.28 \\
\hline $\mathbf{B}$ & \multicolumn{2}{|c|}{ Fixed Costs } & $19,412.98$ \\
\hline 1 & \multicolumn{2}{|c|}{ Rental Value of Owned Land } & $16,744.25$ \\
\hline 2 & \multicolumn{2}{|c|}{ Rent Paid For Leased-in-Land } & 0.00 \\
\hline 3 & \multicolumn{2}{|c|}{ Land Revenue, Taxes, Cesses } & 14.89 \\
\hline 4 & \multicolumn{2}{|c|}{ Depreciation on Implements \& Farm Building } & $2,027.61$ \\
\hline 5 & \multicolumn{2}{|c|}{ Interest on Fixed Capital } & 626.23 \\
\hline $\mathbf{C}$ & \multicolumn{2}{|c|}{ Operational Cost + Fixed Cost $[A+B]$} & $67,650.26$ \\
\hline $\mathbf{D}$ & \multicolumn{2}{|c|}{ Managerial cost } & $6,765.03$ \\
\hline $\mathbf{F}$ & \multicolumn{2}{|l|}{ Total cost $[\mathrm{C}+\mathrm{D}]$} & $74,415.29$ \\
\hline
\end{tabular}

Table.2 Per hectare cost of cultivation of groundnut under solar irrigation system

\begin{tabular}{|c|l|c|}
\hline S. No. & Particulars & Amount (₹) \\
\hline $\mathbf{1}$ & Cost A1 & $34,820.05$ \\
\hline $\mathbf{2}$ & Cost A2 & $34,820.05$ \\
\hline $\mathbf{3}$ & Cost B1 & $35,446.28$ \\
\hline $\mathbf{4}$ & Cost B2 & $52,190.53$ \\
\hline $\mathbf{5}$ & Cost C1 & $50,906.02$ \\
\hline $\mathbf{6}$ & Cost C2 & $67,650.27$ \\
\hline $\mathbf{7}$ & Cost C3 & $74,415.29$ \\
\hline
\end{tabular}


Table.3 Per hectare returns of groundnut under solar irrigation system

\begin{tabular}{|l|l|r|}
\hline S. No. & \multicolumn{1}{|c|}{ Particulars } & \multicolumn{1}{|c|}{ Amount (₹) } \\
\hline $\mathbf{1}$ & Main product & $90,693.74$ \\
\hline $\mathbf{2}$ & By product & $9,751.67$ \\
\hline $\mathbf{3}$ & Gross return & $1,00,445.41$ \\
\hline $\mathbf{4}$ & COC & $67,650.26$ \\
\hline $\mathbf{5}$ & Cost C3 & $74,415.29$ \\
\hline $\mathbf{6}$ & Net return & $26,030.12$ \\
\hline $\mathbf{7}$ & Net Income = Irrigation charges + Net return & $30,350.31$ \\
\hline
\end{tabular}

Table.4 Regression coefficients of variables included in the regression model

\begin{tabular}{|l|c|c|c|c|c|c|c|}
\hline Particulars & Intercept & $\begin{array}{c}\text { Human } \\
\text { Labour }\end{array}$ & $\begin{array}{c}\text { Machine } \\
\text { Labour }\end{array}$ & Seed & Fertilizer & Irrigation & Manure \\
\hline Coefficients & -0.0582 & 0.4047 & 0.1978 & 0.4546 & -0.1970 & 0.2439 & 0.1043 \\
\hline t Stat & & 2.6840 & 2.9120 & 2.3369 & -1.0600 & 2.0544 & 0.6942 \\
\hline P value & & 0.0095 & 0.0051 & 0.0229 & 0.2935 & 0.0445 & 0.4903 \\
\hline & $\sum \mathbf{b}_{\mathbf{i}}=\mathbf{1 . 2 0 8 3}$ & & & $\mathbf{R}^{\mathbf{2}}=\mathbf{0 . 8 0 5 9}$ & \\
\hline
\end{tabular}

Significant at 5 per cent level.

Figure.1 Share of different factors in cost of cultivation of groundnut under solar irrigation system

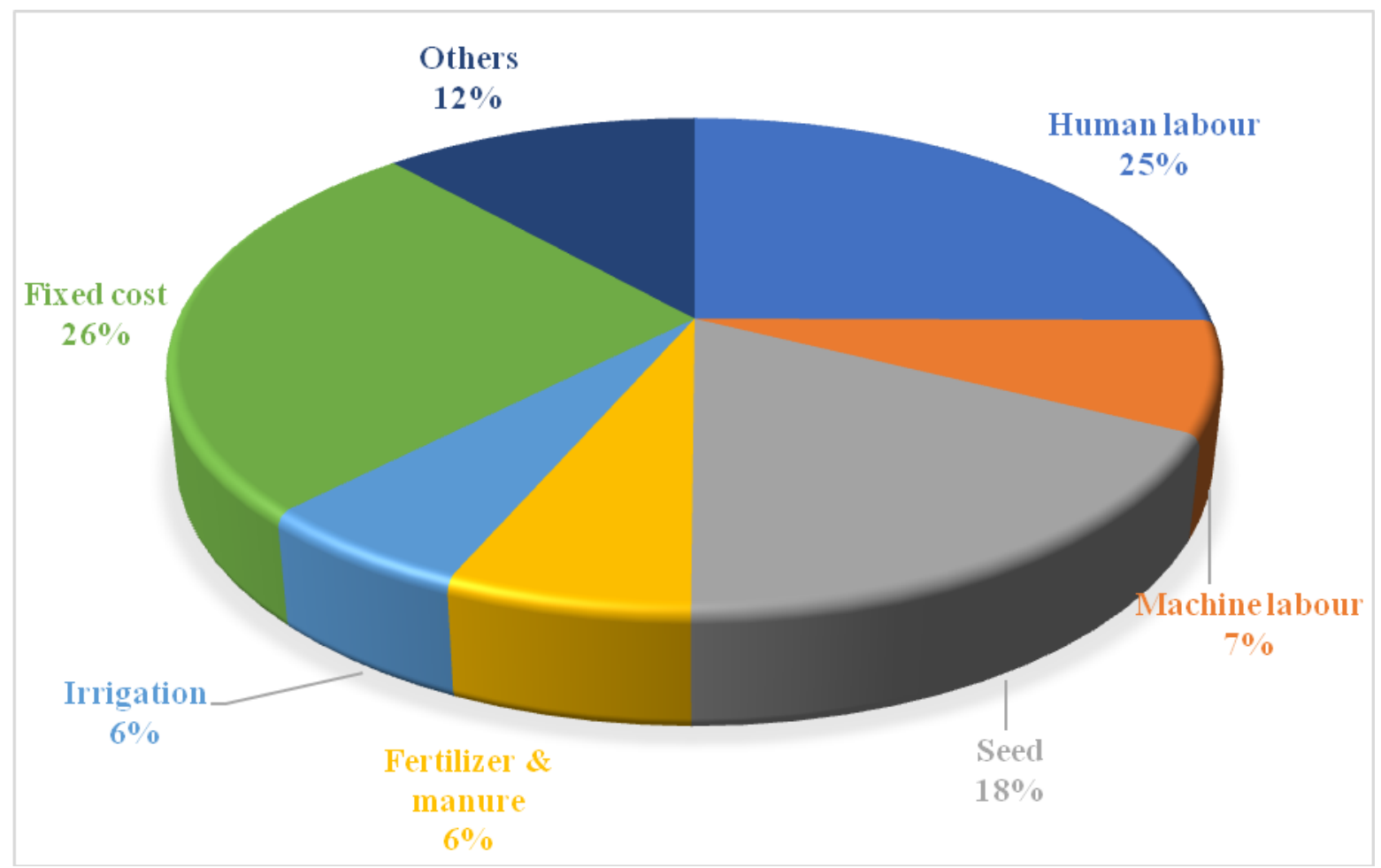




\section{References}

Agricultural and Processed Food Products Export Development Authority. (n.d). Groundnut. www.apeda.gov.in. Retrieved on October 12, 2020, from website http://apeda.gov.in/apeda website/SubHead_Products/Ground_Nu t.htm

Gautam, Y. (2017). Economic Analysis Of Sorghum Production In Maharashtra, India (Doctoral dissertation, Department Of Agricultural Economics Institute Of Agricultural Sciences Banaras Hindu University Varanasi221005 India).

Government of India. (2019). Agricultural statistics at a glance. Directorate of
Economics and Statistics. Dept. of Agric. and Co-operation. Ministry of Agriculture, Government of India.

Klynveld Peat Marwick Goerdeler, (2014). Feasibility analysis for solar agricultural water pumps in India. Netherlands.

Nautiyal, P. C., Mejia, D. and Lewis, B. (2002). Groundnut: post-harvest operations. Research Centre for Groundnuts (Indian Council of Agricultural Research- Food and Agriculture Organization).

Yash, G., and Singh, P. K. (2018). Economic analysis of sorghum in Maharashtra, India. International Journal of Agricultural and Statistical Sciences, 14(2), 601-606.

\section{How to cite this article:}

Yash Gautam and Singh, O. P. 2020. Profitability and Resource Utilization in Groundnut Production under Solar Irrigation System. Int.J.Curr.Microbiol.App.Sci. 9(11): 1993-1999. doi: https://doi.org/10.20546/ijcmas.2020.911.236 